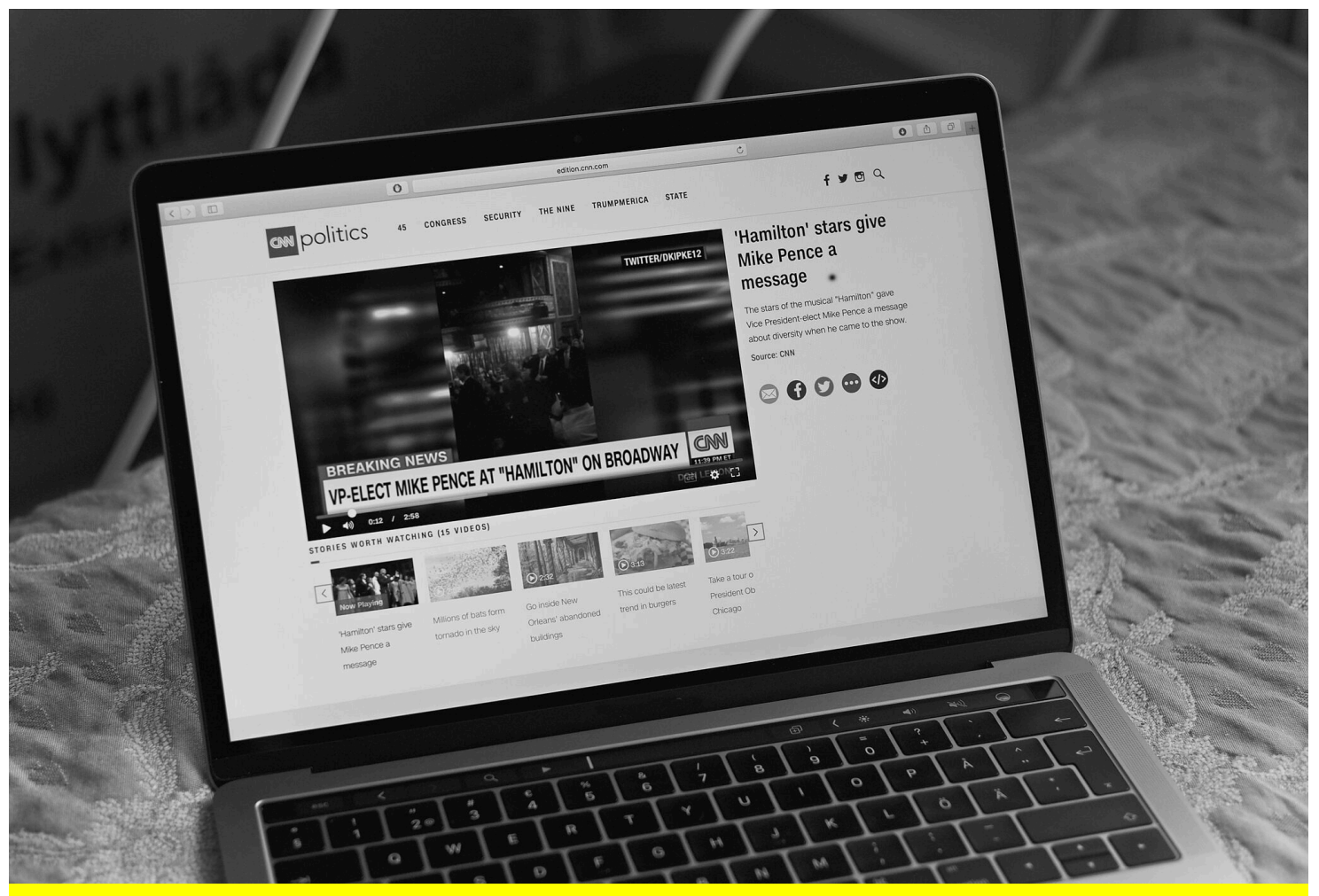

Fig 5.1 Eyewitness video embedded on CNN's website showing Vice-President-Elect Pence as he was protested by the audience on arrival at a Hamilton musical performance.

\title{
How the Ubiquity of Eyewitness Media Changes the Mediation and Visibility of Protests in the News.
}

\author{
Max Hänska \& Mike Bode \\ m@haenska.net - mike.bode.work@gmail.com
}

Keywords: UGC, Amateur images, eyewitness media, witnessing, news, newsrooms, journalism, verification, protest, social media, TV, cross-media agenda setting

Reference: Hänska, Max, and Mike Bode. "How the Ubiquity of Eyewitness Media Changes the Mediation and Visibility of Protests in the News." In Screening Protest: Visual Narratives of Dissent across Time, Space and Genre, edited by Alexa Robertson, 2018, pp. 98-119, Routledge. 


\section{Abstract}

This chapter examines how eyewitness footage travels from the street, through verification procedures in newsrooms, or diffusion on social media until it reaches our screens, and whether its ubiquity, the fact it is now systematically collected, processed and authenticated by newsrooms, has changed the mediation and visibility of protests. It argues that eyewitness footage is polysemic and polyvalent, because it is easily stripped of the context of its original upload, to appear in different contexts, with different descriptions, advancing different interpretation of events and different political goals. Eyewitness media of protests complicates journalism's task of providing a trusted record of the present.

\section{Acknowledgment}

We are indebted to Aleksandra Galus for her research assistance, to Alexa Robertson for valuable comments on multiple drafts of this chapter, and to all our interviewees for taking time out of their busy schedules to speak with us.

\section{Bios}

Max Hänska is a Senior Lecturer in Digital Journalism and Media Discourse at De Montfort University in Leicester, and an associate at the LSE's Civil Society and Human Security Research Unit. His research explores the impact of digital technologies on political communication and citizen journalism. He holds a PhD in Media and Communications from the LSE.

Mike Bode is a visual artist and researcher. His works, which are often developed collaboratively, utilize different types of media such as video and photography as well as architectural and spatial interventions, digital imagery, archival material and texts. One of his areas of interest is the effect that digital technology is having on images and their patterns of distribution. He holds a PhD in Fine Art from Valand Academy, Gothenburg University. 
In November 2016 - after the election of Donald Trump but before his inauguration as US president - a performance of the lauded Broadway musical Hamilton was attended by Vice-President-Elect Pence. The image above (Fig. 5.1) is taken from footage of Pence as he arrived at the theatre, when he was allegedly booed by some of the audience in an apparent act of protest. A second, more widely publicized act of protest took place that night: After taking their bows the cast came back on stage to read a letter to Pence expressing concern that the new administration would not respect the diverse America' they represented. The musical had attracted attention for its use of rap in the narrative and the casting of non-white actors in the roles of the country's Founding Fathers. As Variety magazine pointed out, many in the audience found it ironic that a conservative with a record of opposing gay rights would attend a show on this topic that featured homosexuals, immigrants, people of colour and revolutionaries (Saperstein, 2016). The image we opened on above was not captured by a professional reporter or news crew, nor was it distributed through an agency. It was recorded by an eyewitness on their smartphone, published on Twitter, widely diffused, and then immediately taken up by established news outlets such as the Huffington post, the Guardian, CBS News, and CNN, amongst others.

Most protest events would not enter wider public discourse without videos, images and reports that surface in the news, and on our social media feeds. After all, it is through our television, smartphone and computer screens that we see much of the world. At the same time, the ubiquity of smartphones has made documenting protests and other news events an almost quotidian activity. According to a Pew study $12 \%$ of social media users have posted their own videos of news events, and $11 \%$ of online news consumers have submitted their own content to news organisations or blogs (Olmstead et al., 2014). From Moldova and Iran in 2009, over the Arab Spring to Zimbabwe in late 2017, eyewitnesses filmed both large-scale violent uprisings and peaceful, small-scale protests, like the Hamilton cast and audience's confrontation of Pence. They shared their footage online, and sometimes submitted it directly to dedicated portals like CNN's iReport or France 241.

A growing body of scholarship examines the importance of social and mobile media in facilitating the circulation of protest artefacts and footage, and the importance of this to mobilization and participation (Bennett and Segerberg, 2011; Gil de Zúniga et al., 2012; Milan, 2013). Using smartphones and social media to document, and communicate protests to a wider audience has emerged as a clear trend, in which bystanders and protesters act as citizen journalists (Hänska Ahy and Shapour, 2013; Poell and Borra, 2012; Tufekci and Wilson, 2012). Indeed, documenting protests, sharing and promoting footage appears to have become an integral part of protests themselves, and an important consideration for protest organizers. Most protest events are now characterized by the ubiquity of smartphones held above the crowd to record events. As protesters and eyewitnesses become more involved in the production and circulation of news about protests, eyewitness footage has also become increasingly important to our visual encounters with organized dissent (Wardle et al., 2014). Eyewitness material diffuses through social media, and across the interface between social and broadcast media: We see reports on our social media feeds, and similar ones on the evening news.

But the screens on which we encounter footage of protests do more than mediate, they can become sites and instruments of protest themselves. This starts on the streets, where recording, or live-streaming events creates a kind of accountability structure-we document events for the world to witness. At the same time the media ecology through 
which these images or videos surface on our screens, through which they are circulated, displayed and consumed has been transformed by the mainstreaming of social media. While many protesters and bystanders now participate in the production and diffusion of protest frames and images, those of us who engage with these images and stories of protests through our social feeds are participants too, in the mediation and re-mediation of protests. As cross-media diffusion of protest footage and frames becomes increasingly important, processes of mediation hybridize, interlacing and fusing different media systems and their internal logics (Chadwick, 2017).

This chapter explores these changing processes and practices through which eyewitness footage of protests is created and diffused, and what these changes may mean for the mediation of dissent. After an overview of the burgeoning literature on what is sometimes (albeit problematically) referred to as UGC (user-generated content) or (even more problematically) 'amateur footage', it presents insights gleaned from interviews with journalists, digital editors, digital and news consultants. It explores how newsrooms work with and respond to eyewitness footage, and by tracing examples of the emergence and wider circulation of such footage-understanding these phenomena requires a focus on both newsrooms and the ways content can spontaneously emerge and spread. We argue that the role of eyewitness footage in the mediation of protests illustrates a broader point of how visual material on social media comes to mediate events, how this material is polysemic and polyvalent, how it can come to shape the agenda and narrative around protests, and how it can be instumentalized by different actors for their purposes.

\section{The emergence of eyewitness footage}

Social media separates the task of content creation, from control over the channels of distribution, affording anyone the opportunity to publish content, and everyone the opportunity to engage, share and promote it. Production is now distributed, while diffusion increasingly depends on audiences self-selecting what they want to see, and pushing content to their networks. Needless to say, people everywhere are grappling with these changes. Here, the media practices of protest and activism, witnessing, citizen or participatory journalism, and news professionals intersect in the production and circulation of protest footage. While some maintain that smartphones, camcorders and social media, and non-professionals keen to use them, brought about only marginal changes in the news environment (Curran et al., 2016; Hadland et al., 2017), others argue that professional news outlets have become increasingly reliant on footage provided by citizens (Mythen, 2010), that they sometimes actively solicit it (Grayson, 2015), and that traditional journalistic practices and ethics have been affected by it (Andén-Papadopoulos and Pantti, 2011). To some degree, at least, the involvement of non-professionals in news production and distribution has eroded the distinction between producers and receivers of news (Rosen, 2008; Holton et al., 2013; Kperogi, 2011; Paulussen et al., 2007).

It is noteworthy that witnessing is central to participation in news processes (Allan, 2015). When non-professionals engage in news processes, these are mostly people who are part of the community involved in events, who publish photos and videos, often live from the scene (Grayson, 2015). Before the widespread availability of online, social and mobile media witnessing was phased into 'private experience' followed by 'public statement.' Now it has been transformed into a participatory act, where, as Peters (2001) observes, the hitherto distance between experience and public statement has collapsed (see also: Pantti 
and Sirén, 2015). Using their smartphones, those witnessing news events can now share their experience synchronously.

Questions of nomenclature have arisen over how to designate this kind of footage of news events. The most recognized term, perhaps, is UGC, which designates any media content produced by non-professionals (Greenwood and Thomas, 2015). Yet the term is considered problematic, even by scholars who use it (Harrison, 2010; Wardle et al., 2014), not least because of its techno-determinist connotations (Johnston, 2017). It has also been argued that UGC appears to be a neutral term when it actually masks a situation whereby its creators are being co-opted by corporate media, providing free content and augmenting their dominance in the media circuit (Kperogi, 2011). References to 'amateur images' are also problematic, especially in the wake of the Arab Uprisings, during which activists received feedback from professional newsrooms about their editorial requirements (Hänska Ahy and Shapour, 2013) and were trained in video skills. As one man interviewed by Andén-Papodopoulos explained, with reference to Syrian activists: 'They have learned a lot over time, how they should do to film' (2013b, p.2194). Similarly, Sadiki (Sadiki, 2012)has referred to 'hundreds of dedicated foot soldiers (video users, cameramen, analysts, reporters) who relay information and break news and events expeditiously to the world almost instantaneously, certainly faster than most professional news agencies'.

Instead of amateur images, Andén-Papadopoulos and Pantti refer to 'citizen eyewitness images' (2013a) and 'citizen camera-witnessing' (Andén-Papadopoulos, 2014). As noted, witnessing is indeed integral to the phenomena described. We will use the term eyewitness media, or footage. Importantly the term permits us to remain agnostic about the role of those who create and share footage, as it allows for a whole spectrum of participation, that the contrast between passive recipient of media messages and active users does not satisfactorily capture (Van Dijck, 2009). After all, little is usually known about the motivations of those who record and share footage (e.g. whether they intended for it to reach a wider audience, or be used by newsrooms). Eyewitness media can include, but is not limited to news or reporting (Holton et al., 2013). This ambiguity, concerning motives and practices of actors involved, is an important part of these distributed phenomena through which information and visual material about news events reaches audiences around the world.

\section{Mainstreaming eyewitness media in Newsrooms}

As eyewitness media has become ever more abundant and more readily accessible, newsrooms have started to make greater use of it. Journalists often draw on it when images or footage could otherwise not be obtained, either because reporters are late to the scene, or because they simply lack access for other reasons (Williams et al., 2010). Above all in situations where journalists face constraints to on-the-ground reporting eyewitness media can be an invaluable resource (Mast and Hanegreefs, 2015). Eyewitness media provide new avenues for reporting, and creates opportunities for non-professionals to enter the media circuit, particularly in crisis or conflict situations (Carruthers, 2011; Matheson and Allan, 2009; Seib, 2007), where they provide first-hand accounts that would otherwise be unavailable.

London's $7 / 7$ bombings were the first instance where eyewitness material was readily available (because mobile phones increasingly had cameras at the time) and used by news organisations (Hadland et al., 2017). On 7 July 2005 the BBC famously lead a news bulletin with the grainy, low resolution eyewitness footage recorded on a cameraphone of 
the light at the end of a London Underground tunnel as passengers evacuated on foot (Wardle et al., 2014). It is perhaps the first widely recognized piece of eyewitness media of the digital era. After the bombings the BBC established its UGC processing hub (a software platform and team dedicated to handling eyewitness material) (Wardle et al., 2014). A year later, in 2006, CNN launched its iReport, an initiative to make better use of citizen journalists. But it was not until the protests that followed the contested 2009 election in Iran that the BBC's UGC hub became fully integrated into newsrooms. During the protests eyewitness media became a primary source of information, and was central to news processes around the world. Subsequently UGC played a key role in the way the world witnessed the uprisings across the MENA (usually called the Arab Spring). As Matthew Eltringham, one of our interviewees noted 'what's happened since 2009, inside and outside of the $\mathrm{BBC}$, is a professionalization [in dealing with UGC], there is an understanding that this can't just be left to chance' (interviewed 26 October 2015, London).

Iran's elections were a crucial turning point for several reasons (Hänska Ahy, 2016; Hänska Ahy and Shapour, 2013). Firstly, many people owned mobile phones capable or recording images, or at least digital cameras. Secondly, Internet access was widespread, and bandwidth sufficient to make uploading images and video easily feasible. And lastly, when people spilled onto the streets after what they thought must have been a rigged election, the Iranian government attempted to institute an immediate media blackout. International media, who many Iranians turn to for news, were unable to cover events themselves, and so turned to eyewitness media as readily available sources for reporting the protests. The situation was unique, because for the first time there plenty of eyewitness footage was available and discoverable at a distance (unlike the recordings of the 9/11 attacks where video tapes needed to be physically transferred), while conventional sources of information (journalists on the ground) became unavailable during a major international news event. In the subsequent, so-called, Arab Spring, eyewitness media played an important role in reporting events from Tunisia, to Egypt, Libya, and Syria (Murrell, 2017). These events marked the first time that eyewitness media was systematically used as a primary news source (previous uses were mainly to supplement lighter stories) (Harkin et al., 2012). Since 2009 Western news outlets are increasingly drawing on eyewitness material (Mythen, 2010). Furthermore, as Grayson (2015) notes, news organisations are increasingly encouraging citizens to contribute to news sites, sometimes even cooperating with citizen journalists-though some caution us not to overstate how much eyewitness media is actually being used (Hadland et al., 2017).

While in many ways a boon, however, eyewitness media also create a whole new set of challenges (Browne et al., 2015). Above all, it is often seen to lack institutional authority, as it is not self-regulating in the way news organisations, which adhere to conventional journalistic checks and balances, are (Bock, 2012; Mythen, 2010). When journalists come to rely on eyewitness material there is a trade-off between its use and their professional values of veracity and accuracy, which leads them to either verify eyewitness media or distance themselves from responsibility for its accuracy (Pantti and Sirén, 2015). It creates the need to discover and verify the authenticity of footage, requiring some reorganisation of news processes, and new sets of journalistic skills (Johnston, 2016). To address these challenges, news organisations followed the BBC's and CNN's example to develop units dedicated to working with eyewitness media. News agencies also started supplying their clients with verified and rights-cleared eyewitness material. Storyful, a social media news agency that specializes on discovering, verifying and distributing eyewitness footage to subscribers, was founded in 2010, and in 2013 the Guardian 
launched GuardianWitness, an app for citizen journalists. Eyewitness media has changed the way journalists access, process and work with news footage.

But eyewitness media provides more than first-hand material that journalists would otherwise lack, it also opens alternative ways of reporting a story. For instance, eyewitness footage shifts the visual aesthetic and experience of news. Handheld smartphone footage (perhaps shaky, gritty, or recorded in portrait mode) lends an authentic immediacy and sense of proximity to news events that appeals to audiences, and may help increase viewership (Andén-Papadopoulos and Pantti, 2011; Pantti, 2013; Pantti and Sirén, 2015; Wahl-Jorgensen et al., 2010). Matthew Eltringham explained that 'The authenticity that user generated content provides, adds value.' A recent Knight Foundation study found that many young people in the US find UGC, especially live video, more trustworthy than traditional news sources (Madden et al., 2017). The image of the London bombings, video footage of the Sri Lanka tsunami, or indeed footage from hurricane Sandy are widely recognized. Their eyewitness quality places the viewer in the midst of events. Consider also the countless videos circulating of police brutality, in the vein of the Rodney King tape. Hand-held, sometimes grainy, or portrait mode video often add to the compelling up-close quality of eyewitness media. Where professional news footage can be experienced as distanced - holding the viewer at arm's length - eyewitness media is thought to provide an authentic immediacy, which has helped establish its value in the newsroom.

The big question is whether these developments have changed processes of news gathering, and the way the meaning of news events is constructed (Lorenzo-Dus and Bryan, 2011). Some have argued that eyewitness media challenges the way events are mediated by elites, the way mainstream media cover them, and how online publics are invited to bear witness to them (Steel, 2015). Today, as participants, bystanders or those affected bear witness, they share their experience online-what Mortsensen (2015) refers to as 'connective witnessing.' Mobile, digital and social media afford citizens and protesters new opportunities to share their own images, videos and perspectives on events they witness. They also afford them new ways of selecting what they want to see, and ways of promoting content to their networks.

\section{From street to screen}

When do newsrooms pick-up such footage from 'the crowd'-filmed by activists or bystanders witnessing tumultuous events - and what happens with it when it finds its way into newsrooms? To find an answer, six in-depth interviews were conducted in 2015 with Alex Murray a specialist in verification and social media at the BBC, Matthew Eltringham, an Executive Editor at the BBC College of Journalism, Fergus Bell who is a journalist and consultant on digital newsgathering and the verification of UGC, an anonymous former digital consultant at BBC World Service, Caroline Bannock, an editor for community and UGC at the Guardian, and Eric Tucker, the co-founder of an online advertising company. The interviews, the transcripts of which were subjected to thematic analysis, focused on the use of eyewitness material in newsrooms, how it was acquired, verified and used for news stories. In addition to insights gleaned from the interviews, a set of examples was used to trace the emergence, spread and impact of UGC in real time. We realized quickly that it was hard to reconstruct the emergence and spread of eyewitness footage after the fact, which is why we focused on tracing and collecting information about their dissemination in real-time, collecting and searching for material as it emerged (not unlike the work 
journalists would do in searching and ascertaining the veracity of eyewitness footage). These examples serve as illustrative case studies.

\section{Search and collection}

Eyewitness footage is now systematically collected, processed and authenticated by verification hubs and media agencies on a daily basis, a process starting with the discovery and acquisition of relevant UGC. There are two routes through which eyewitness footage reaches newsrooms, as Alex Murray explained: inbound to us (sent to the BBC) or outbound discovery by search and intelligence gathering. Often we work with other departments, like our international bureaux and BBC Monitoring, to establish a list of potential sources of credible material' (interview 28 October 2015, London). Some footage is submitted directly through email, WhatsApp, direct message on Twitter or, where available, through special facilities made available by news organisations. Most eyewitness footage is posted on social media, however, so that newsrooms need to discover it themselves. When a story is developing, they will trawl through various social media streams, following accounts with established reputations for curating or sharing relevant content. This is often a de-centralized process in which different departments collaborate.

Those who record and share eyewitness footage can ensure their content is found more easily by tagging and placing it appropriately. But news organisations also reach out, as illustrated by Andy Carvin's (of NPR) approach to social newsgathering during the Tunesian uprisings (Harkin et al., 2012). Carvin crowdsourced information not only by discovering content on social media, but also by reaching out to audiences to help verify it. As Caroline Bannock explained during our interview:

We do both searching and also asking. So, for instance, if there is a protest in Turkey then we would publish a GuardianWitness call asking people to 'share your content', and they do. We also remind them to think about their security first before they share. We started thinking about other ways people could share with us, and we use Chat apps such as WhatsApp as well. For the Pakistan earthquake the best video was sent into via WhatsApp. It wasn't put out there [on social media], it was actually sent to us. (Interview 28 October 2015, London)

There is also evidence that, as this desire for content from the front lines was recognized by non-professional contributors on the ground, some started professionalizing their approach to recording and sharing footage, by making it more discoverable, or sending it directly to newsrooms.

\section{Verification practices}

Journalists are, of course, bound by a set of cultural norms and values which define their professional identity, and which in turn shape their practices of reporting (Hanitzsch, 2007; Schudson and Anderson, 2009). To report on the world means to ascertain the facts in order to determine what is actually happening, rather than what social media users claim to be happening. Eyewitness footage can be used to accompany a story about which the facts are fairly well established (as it was during London's 7/7 bombings), or as a source to figure out what the story is in the first place (as during Iran's post-election protests, or during the Arab Spring).

In either case, eyewitness media needs to be verified to ascertain its authenticity, and a number of processes and skills have been developed in recent years to this end. As 
Matthew Eltringham told us: 'in an ideal world [the verification of eyewitness footage] is a core skill that journalists coming into the profession should have' (interview 26 October 2015, London). In the context of protests, scepticism towards UGC may be deepened by questions about the motivation of uploaders, as Caroline Bannock explained:

It's harder when it's a piece of content that you discover online. I remember protests in Oakland, in California, there was some looting going on. Some activists could get really close to the scene because the community knows them, and they are using Bambuser to live stream. And I thought the video was really strong, but actually at that time we were really wary about using it: A, they are activist journalists, and B what they are doing seemed to almost be inciting people to do more of what they are doing. But at the same time I thought it was such an interesting phenomenon we should be reporting on. [...] People are very wary now about the stuff, the content in protests, about the best way to use it - and it's really important to be transparent about who the uploader is - i.e. are they an activist or a bystander. (Interview 28 October 2015, London)

Verification is thus the key stage of the process through which images recorded by eyewitnesses are incorporated into the reporting of mainstream media. Verification is of particular importance when journalists are concerned that the material may have been provided for instrumental reasons, to advance the political agenda of activists for example. To mitigate the risks of misreporting, or being saddled with misleading content, newsrooms take an image or video discovered by or submitted to them, and try to determine the place it shows, the time it was recorded at, and the nature of the event depicted. Once useful and relevant eyewitness footage is discovered, there are two principle avenues for verifying it. In the first instance, newsrooms try to trace the origin of a particular image or video by searching for the original uploader. It is quite common for newsrooms to identify the likely source of footage that is being shared across social media, and if they do, they contact the original uploader to ask whether they captured the content themselves, what kind of equipment they used to capture the image (i.e. model of camera or phone), time of day, location and other contextual information about the recording that can be used in verification. If contact with the original uploader can be made, newsrooms will also ask for permission to use their content. As Alex Murray explained:

We will do everything we can to find the earliest upload and then aim to contact that person as the original source. That means initiating direct contact by whichever platform they are on. We never run anything without first trying to contact the presumed copyright holders. It's increasingly difficult with chat apps and in places where aggregators supply the bulk of material. But usually we can tell who is the likely source and so qualify the ways we can get permission - our licence is always non-exclusive and in return for a credit. We generally don't pay for UGC but we do not attempt to stop contributors from profiting from it by selling it to other parties. (Interview 28 October 2015, London)

Some of this information can also be gleaned from a user account's social history, i.e. whether the history of posts and content shared makes it plausible that the user was in the given location to record the content at the time. 'To verify the source [we] look at their social history, have they posted anything in the run-up to that one piece of content that 
proves that you are there' Fergus Bell explained (interview 27 October 2015, London). For instance, the first images from the 2011 bombings in Oslo emerged from the Twitter account of a tourist who had been posting pictures from Oslo earlier that day, so that his earlier Twitter activity lined up with the images of the attack. When the original uploader can be found, verification is usually relatively easy. Sometimes, journalists develop ad hoc relationships with those who have repeatedly provided useful footage, even though newsrooms may have policies that discourage developing such relationships (there is a risk of encouraging people to put themselves in harm's way to gather content).

Image details

However, it is not always possible to identify the original uploader. Newsrooms then need to engage in image forensics. In some cases the place shown is well known, and journalists will have less difficulty determining the location of a protest, or even the time. Verification often involves speaking with colleagues who know the region. It involves looking for signs of manipulation in the video or image, the 'exif' data (i.e. the image meta data that contains, among other things, the time of recording, and recording device) and asking how the information tallies with the social footprint of the user account that appears to have originated the content, whether information has been scraped from the video or image, and whether it has been edited or manipulated in any form. As Fergus Bell explained:

you are doing things like checking the content with independent experts or experts within you own organization, like someone translating the audio, captions, making sure that any signage or words are translated, that they match the captions etc.. But you will also go outside of the material, in the case of a protest, check with the local authorities ... once you determined that this event happened, and you know its legit, you can match the two together. (Interview 27 October 2015, London)

Sometimes the place, time and nature of events depicted in eyewitness footage are harder to verify than others. Alex Murray noted that 'Geolocation is easy to spoof ... so you have to be very wary of things that are geotagged to be somewhere'. Clues as to the location depicted in the footage are cross-reference with geotagged images found on Google or Bing maps, or other services that allow geographic image searches. The verifier will also look for distinct landmarks, buildings or street layouts and other features that can be matched to other images of the purported location.

The problem of establishing the time at which an image was captured or an incident filmed can be particularly tricky. The climate and time of year of the event supposedly depicted in an image can be compared with seasonal weather patterns. Local weather reports are checked and compared with the direction and length of shadows in images, which can also help corroborate the time of day. During the Arab Spring protests old footage was often circulated but attributed to current events, as Alex Murray explained:

in Libya, we realized very early on how systematic they had become at reusing material, so we were keen to look at time zones, check what time Friday prayers was for instance, you would get material where they said the protests were after Friday prayers, so you would have to look at the clock to figure out if Friday prayers had happened? How likely is it that they have had time to walk out of Friday Prayers for a protest to get under way and for it to have got to the point shown in the footage. 
Sometimes we found that it was chronologically impossible to be from that point. (Interview 28 October 2015, London)

Car number plates and dialects are other clues to the authenticity of footage. Newsrooms will also look for other social media 'chatter' that can be used for corroboration, for instance other videos showing the same event, but from different angles, and shared by independent social media accounts. 'Reverse image search' is another useful tool for identifying the originality of an image by searching for earlier versions of it. Journalists often have their own personal workflows, watching the videos, making notes, taking screen grabs of notable information before cross-referencing with other material and contacts who may have local knowledge.

When the footage being verified is of a protest, the newsroom must also take into account its character, the number of participants and their demographic make-up. Using, for example, maps of the square or street in which the protest took place, it is possible to estimate the size of the turnout. Multiple images with different angles showing the same protests are important, as the angle and frame of a photo can be used to stage events in ways that makes a crowd look larger or smaller, happy or angry, peaceful or violent. An example is instructive here. In the early days of unrest in Libya in 2011, before protests had turned to rebellion and then civil war, the $\mathrm{BBC}$ received video footage which was said to depict large protests in the city of Misrata. As the BBC UGC hub was unable to track down the source of the video, it began using other means of ascertaining its veracity. Alex Murray explained that

in Mistrata it took a while to understand the geography of the main square, so we would do things like count the number of trees, they have these beautiful Italian box trees on one side of the square, so we would check that it was the right square by counting the number of trees on the side of the square, and then we would figure out, if that's over there then he must be on this side, and then look at road markings on a map, how many lanes wide is this? I use the idea of a big venue like Brixton academy which holds about 3500 people, so when someone says to me that at this protest there were a 100.000 people, then you think that's like Wembley plus a bit, so does this visually look like the same as Wembley plus a bit standing on the pitch? I usually work on the basis of shoulder width, the space one person takes up is probably about $50 \mathrm{~cm}$ per persons shoulder width, ... so you get to understand the size of a space and how many can fit in, you count the rows, ... and do the maths then ask how big is this town, and what percentage of the population is it? (Interview 28 October 2015, London) 


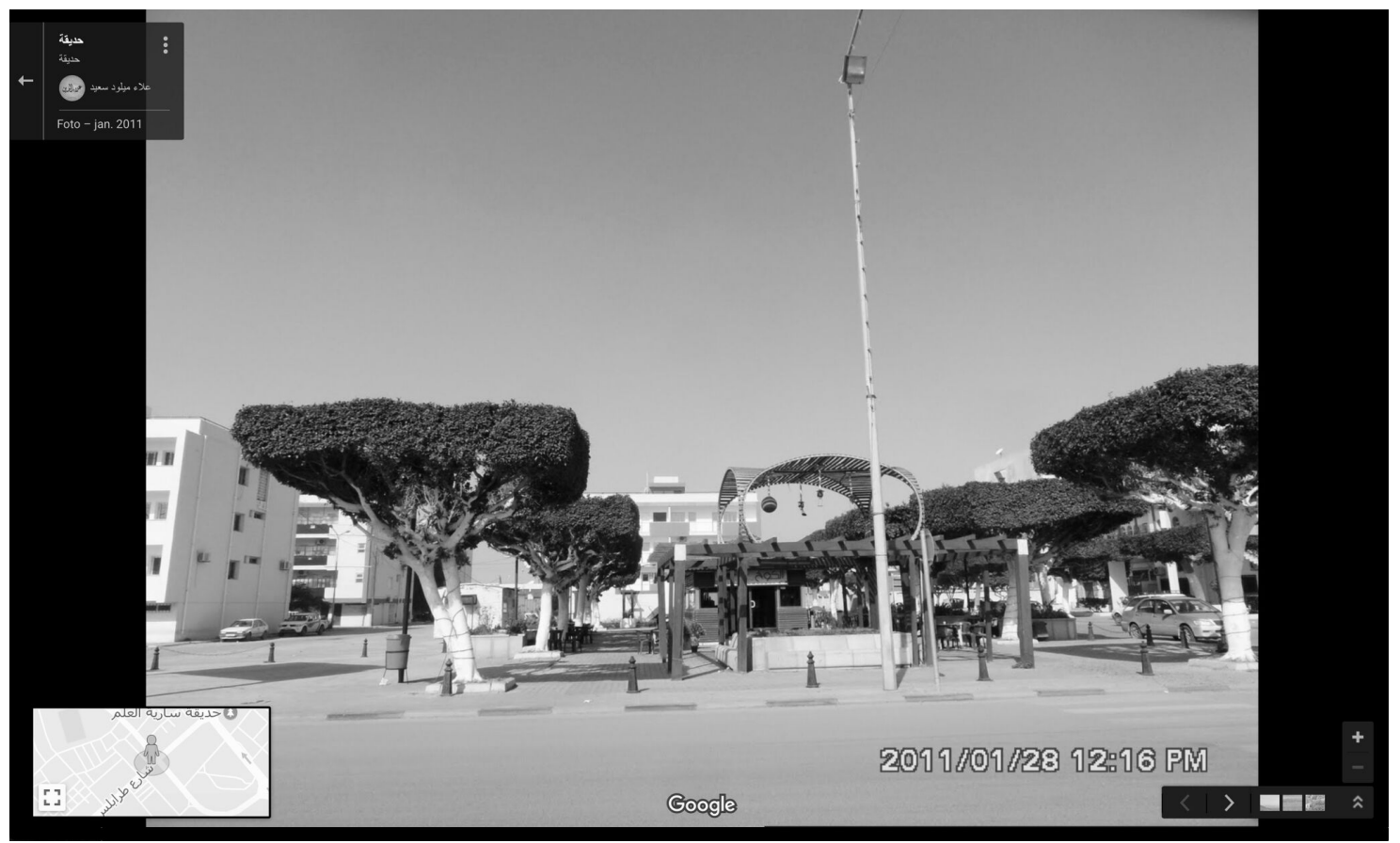

Fig 5.2 Shows one of the many reference images used by verifiers at the BBC to verify the site of eyewitness footage of protests. In this case a screen annotation from Google maps showing Italian box trees which were used to ascertain the geography and spatial orientation of the Square in Misrata.

By counting the number of Italian box trees (seen in Figure 5.2) on one side of the square Alex Murray could ascertain that it was indeed the correct place. By looking at road maps, he could see how many lanes wide it was, and from this information calculate the size of the square and then determine the approximate size of the protesting crowd. By comparing this to Misrata's population, it was possible to work out the proportion of the population out on the streets that day.

Sometimes this work takes place against breaking news deadlines, yet footage may require a slower background trawl to verify. In 2015, during the Paris (in January at Charlie Hebdo, and again in November) and Tunisian attacks eyewitness material was on air within an hour of initial reports. When Gaddafi was caught by Misrata rebels, one of our interviewees explained how he verified the video footage in 45 minutes, enlisting the help of a Libyan colleague and phoning contacts on site in Libya.

Different newsrooms have different principles regarding the threshold of certainty required before clearing eyewitness footage for use. Fergus Bell noted that

with material from breaking stories, it depends on policy, some will put out videos that are being talked about so as not to seem slow to get the video out, [...] I think it's more valuable to put things out there only when it's been verified. I think this is happening more now, that people are aware and are holding back [...] because you audience can see that anyway, they know how to search for things on YouTube, they are coming to you to get the context and to have it confirmed as real! (interviewed 27 October 2015, London)

On clearing content for use Alex Murray elaborated that:

We have principles and key pieces of information which we need to be sure of before we clear material. But everyone has their own personal 
workflow within that which allows them to work towards the same result....one person does and initial check and gathers evidence, then we'll do a peer review of each other's work if we have any specific concerns. So we'll show what we can match up and what we can't and decide if we feel that is strong enough evidence. (Interview 28 October 2015, London)

Ingestion

After verification, eyewitness footage can be incorporated into news stories. Typically, only a few short sequences of the verified material are used, even if much more material is verified to ascertain the facts of a story. Sometimes debates arise in newsrooms about which footage is best suited for a story: good but shaky versus clear but less dramatic footage. Initially the appeal of eyewitness footage was at least partially its authentic, frontline character. But as smartphones increasingly have high resolution cameras, image stabilization, and support $4 \mathrm{k}$ video and integrated post-processing, their results look distinctly less amateurish. The rise of amateur drone footage and the enhanced quality of eyewitness material makes it increasingly difficult to distinguish from professional content. The sense of authenticity which once derived from shaky, low resolution, or blurred images is thus on the wane, leaving only awkward camera movements and bad angles giving eyewitness footage an amateurish character. One exception, perhaps, is video filmed in portrait mode. So much so, that some news sites, including the BBC news app now support video in portrait mode. As Alex Murray elaborated:

the quality of the material has changed dramatically, not only technologies, but also [depending on where ...] things happen. [UGC from] Tunisia and Iran were pretty low resolution in terms of the video quality and stills, get to Libya and its really high resolution, those guys shoot $1080 \mathrm{HD}$ on the latest smart phones because they can afford it, likewise in Syria in the big cities. So you can tell a bit about authenticity from the kit people are using. ... You can also tell if it was professionally produced just by the movement within the frame, so the way that a frame moves, is very different hand held to the way if it's shoulder mounted. There is just a very sort of distinctive physical sense within the image, you get those little sort of wobbles and tears when it's a phone that you wouldn't get with a more prosumer kit or DSLR. (Interview 28 October 2015, London)

For protest movements, footage coming into wider circulation through the news can have a dual function. Firstly, it puts images and narratives about protests into the wider public discourse. Secondly, coverage in the news gives events an official character. If we witness a protest through images that surface on our social feeds, we gain awareness of them. When these images are used by the $\mathrm{BBC}$ to report the protest, they become seemingly undeniable facts, corroborating activists stories about protests.

When there are multiple videos in circulation an important question arises about which is most suited. Does one show the front or the back of a protest, which is most salient to the story? A good example is the eyewitness footage that opened this chapter-a blurry video from the theatre where Vice-President-Elect Pence was reportedly booed by the audience. Different videos of the event were screened by news outlets including the Guardian, CBS News, the New York Post, CNN and the Washington Post. In Sweden, it 
was reported on Dagens Nyheter, Svenska Dagbladet, and the Expressen daily newspaper's websites. Storyful acquired a video and made it available to subscribers of its social media news wire-yet different footage lent itself to tell the story in a range of distinctive hues. One video that circulated online and that was picked up by the Huffington post seems to suggest overwhelming boos. But another video, also making the rounds and picked up by $\mathrm{ABC}$ News, suggests that the boos were mixed with cheers, in line with Pence's own account of the evening.

\section{Social media increasingly setting the pace of our news agenda}

The plentitude of eyewitness footage, and in some cases dependence on it, has consequences for news values and for the way stories of protest are told. As Gamson And Wolfsfeld (1993) have noted, the relationship between protests and media is characterized by a struggle to control the narrative and establish the meaning of protest events in public discourse. Eyewitness footage has not changed this, but while journalists select stories and decide how they are framed, they control fewer elements along the pipeline of production compared with the early 1990s.

There are two aspects to this change, which mirror the two ways in which eyewitness material becomes central to the screening of protests: through its use in the news media, and through its visibility across people's social media feeds. In practice the two are interrelated. In some circumstances newsrooms rely on eyewitness footage to tell a story. But that same footage newsrooms use is usually also synchronously available to all social media users. People clutch their smartphones and monitor their social feeds, while the TV broadcasts the evening news in the background. Audiences will inevitably compare TV or press reports with news they encounter on their social feeds (Hänska Ahy, 2016). Charlie Beckett refers to this as the need for news to engage with the 'dark side' of stories, to engage with material circulating on the social web irrespective of their ability to verify or debunk it (Beckett and Eltringham, 2011). Users, after all, can follow events in real-time on their social feeds, putting journalists under pressure to cover stories sooner rather than later, so that speed sometimes trumps verification (Kristensen and Mortensen, 2013). Through such processes the mediation of protests, and the meaning they are given, are shaped less by journalists alone, and more by the interaction between newsrooms, those sharing footage, and those engaging with reports of protests on social platforms. Indeed, for newsrooms to succeed in social media newsgathering a collaborative, cooperative connection between journalists and those who create or provide footage is often required (Allan and Peters, 2015; Hänska Ahy and Shapour, 2013). Furthermore, journalists may be forced to pay attention to eyewitness material that gets sufficient traction on social media, which begins to 'trend.'

But trending is problematic from a journalistic point of view. Firstly, as Alex Murray put it, 'people assume widely that if something is trending that means that it is popular by volume, but what they don't understand is that algorithmically trending means that it is popular by relative volume, so actually [...] a lot of things that people see as trending [...] when you look at the relative numbers it's small' (Interview 28 October 2015, London). Beyond capturing traffic Fergus Bell explained that

trending is useless in journalism. Trending is enough people talking about something already, and really if you are a journalist and if you are not the one giving them the information they are talking about, then you are too late! So trending is just to increase traffic to your site [...]. For 
hard news/real story telling, it's about finding something well before its trending. (interviewed 27 October 2015, London)

Most recently control over the public mediation of protest events seems to have drifted further into the domain of social media, as news organisations' grip over the mediation of events further loosened. By contributing to the mediation of particular protest narratives, by contributing to frames and counter-frames, social media users are turning social platforms themselves into spaces for protest. After all, to publish a partisan take, to share it, to get it trending on social platforms, is itself to participate in advancing, or curtailing the goals of the protest. Framing and counter-framing protests muddies public discourse, confuses us about the meaning of protests, and entices us to fall back on our available prejudices. 'Is it my candidate who is the object of protest? How dare they!' In these ways the circulation and re-circulation of images, the way they are framed in different information spheres, comes to shape public understanding of protests amongst different groups. Alex Murray discussed an example from Syria, where different videos purporting to show the same protest were in circulation. However, there

were pro regime [protests] happening at the same time in the same district as anti-regime protesters. It was very difficult to separate out the two, and there was one particular incident where activists submitted video quite widely [which claimed to show] that this was protesters being chased by authorities away from a protest. But it was a little more complicated [... as] this was possibly just a local dispute about cab fares, and I've seen that sort of thing, a local dispute played off as a protest sort of thing (Interview 28 October 2015, London)

Eyewitness footage circulating on social media is often polysemic and polyvalentit lends itself to different readings, and can be wielded to different ends. This was the case with the Pence video described above (Fig. 5.1), which lent itself to different interpretations and instrumentalizations. Indeed, social media may amplify partisan polarization around issues, as networked diffusion could increase selective exposure to views and information congenial to people's political proclivities. Though a global problem, social media moved into the spotlight after the 2016 US election: President Trump infamously uses Twitter as a direct conduit for reaching those positively disposed to his message, while those who opposed him could share news of Standing Rock, or the women's march that resonated the view that he was unfit to be President.

Consider Eric Tucker's story, a 36-year-old co-founder of an online advertising company from Austin. On 9 November 2016 Tucker tweeted several photos (Fig. 5.3) showing rows of chartered busses, with the original tweet implying that they were ferrying hired, faux anti-Trump protests. He posted: 'Anti-Trump protestors in Austin today are not as organic as they seem. Here are the busses they came in. \#fakeprotests \#trump2016 \#austin'. The tweet was shared over 16.000 times on twitter and more than 350.000 times on Facebook (Maheshwari, 2016). However the buses were not being used for protesters but rather as hotel shuttles for the Tableau Conference being held at the Austin Convention Center. Tucker explained that when he was convinced he had gotten it wrong, he was very

eager to set the record straight. The whole time, I had one guide: my responsibility to others to tell the truth. [...] What surprised me most was the initial traction. How was my post that different from thousands of others during that election cycle? [...Knowing that hitting retweet is 
so easy, amplifying an already viral tweet] I deleted my original famous tweet to prevent it from being further retweeted. [...] I made a mistake in using the hashtag '\#Trump2016'. Use of that tag was intended only to provide context - not convey support. It was a simple, stupid error that led to many thinking I was a Trump supporter [though I didn't vote for him. ...] Twitter has no good mechanism for correcting or clarifying one's tweets. Once something is famous, it's out of the author's hands unless deleted. (Interviewed by email, November 29, 2017)

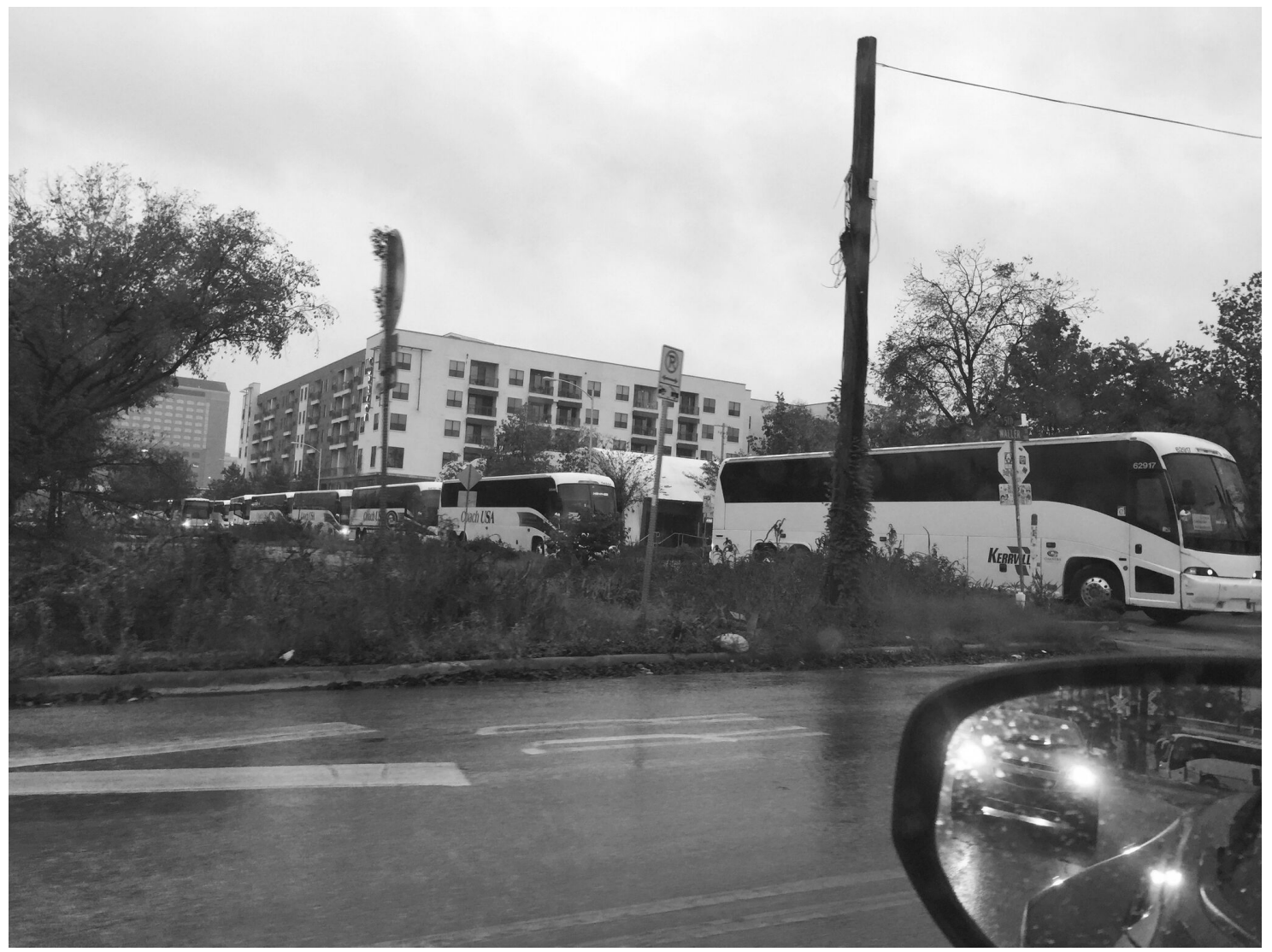

Fig 5.3 One of the Images shared on Twitter by Eric Tucker purportedly showing busses transporting anti Trump protesters which was later re-posted on several websites, and commented on by president-elect Donald Trump fuelling a nationwide conspiracy theory.

Tucker's tweet was posted in a Reddit community of Trump supporters, implying that the images were proof of paid protests. The images and their framing was further spread on other conservative websites and forums, extending their reach. The insinuations were later repudiated by Tucker replying to queries on Twitter and by the bus company. These corrections did not nearly rival the reach of the original post, and are thus unlikely to have debunked the rumours and misinformation-some sites continued to incorporate Tucker's original tweet into posts about paid protesters. This misinformation was further debunked by other website and several news networks, but at that point the tweet and images already had some political impact. Nevertheless, Tucker explained that while the initial inaccurate representation of his post got lots of traction, he did feel that he managed to set the record straight in no 'other than an internationally syndicated article in the NY Times. [...] I was also briefly live nationally on Canadian CTV and separately on local news of FOX7 in Austin. I got to tell my story.' Of course, as Tucker acknowledges, this did not abate the weaponization of his original post, as the 'fake protestor' counter-frame was compounded when Donald Trump tweeted 'Just had a very open and successful 
presidential election. Now professional protesters, incited by the media, are protesting. Very unfair!' The struggle over the interpretation and meaning of protests is being transformed by social media, as multiple meanings are put into circulation around a single piece of eyewitness media, with no one clearly in control.

\section{Conclusion}

This chapter aimed to understand how eyewitness footage of protests surfaces in the news, how these images reach our screens, and what if anything that means for the mediation and practice of protest. Images of protests have always been crucial to the goal of communicating their cause, and activating the support of a wider constituency. From the images of Tahrir Square overflowing with protesters, to online videos of a newly elected vice president being booed as he arrives at a theatre. The message that protests send into wider public discourse has always depended on its mediation, but the processes of mediation have changed as eyewitness footage became ever more prevalent. From public mediation being closely controlled by broadcasters and professional journalists, adhering broadly to a set of professional norms; to a hybrid environment where news competes with eyewitness material on people's social feeds.

It is worth noting that journalism has changed as it has taken on board new sources of news and information, but also as it has been forced to engage with social media chatter more broadly. This chapter has outlined, at least in part, how journalists try to make eyewitness footage compatible with their professional norms and standards: Newsroom routines and practices have evolved around this material, to capture, verify and ingest it into news stories. This is the pipeline eyewitness content will pass through, if it is to make it into the news. But protests themselves have also changed. Mainstream adoption of smartphones has turned documenting protests into an integral part of protesting itself. Engaging with protest narratives on social media can also be interpreted as an extension, or form of protest. While it is clear that journalists control fewer elements along the conduit of production and distribution, complicating if not diminished their control over processes of mediation, it is not immediately clear that this translates into empowered eyewitnesses. Protests may have expanded their scope to self-communicated, but this does not unambiguously signal empowerment.

Most recently social media itself is becoming a battle ground over the interpretation of protests, where footage of protests is wielded by social media users to confirm and further their own agenda. The challenge both protesters and journalists face is that decontextualized footage floating around social media is polysemic and polyvalent. Multiple meanings can be put into circulation around a single piece of footage, each congenial to different ends. Footage, often recorded by protesters as irrefutable evidence of events, as authentic front-line eyewitness media, are circulated through a murky media ecology where that same footage can be turned against their cause. Eyewitness material is malleable, it assumes meaning only within the context that users create by engaging with it, or indeed that journalists create by ingesting it into a news story. While journalists need to ensure eyewitness material conforms to journalistic standards of truth and accuracy, social media users are beholden to little more than their instincts and impulses. And that makes for unpredictable processes of mediation.

In a sense these developments constitute a departure from the hybrid mediation of protest events, where journalists played a key role in both fact-checking and framing the reports of protests, even if the influence of eyewitnesses and social media was on the rise. 
Now it seems improbable that traditional news outlets would be able to inflect a dominant narrative once it takes hold. Instead, we are witnessing traditional news media playing catch-up, as the frames circulating and trending on social platforms increasingly determine the meanings of protest events. This also reshapes protests, as social media becomes an increasingly important battle ground for the framing of protests themselves.

\section{Bibliography}

Allan, S. (2015) 'Introduction', Journalism Practice 9(4): 455-464.

Allan, S. \& Peters, C. (2015) 'Visual truths of citizen reportage: four research problematics', Information, Communication \& Society 18(11): 1348-1361.

Andén-Papadopoulos, K. (2014) 'Citizen camera-witnessing: Embodied political dissent in the age of 'mediated mass self-communication", New Media \& Society 16(5): 753769.

Andén-Papadopoulos, K. \& Pantti, M. (2011) Amateur Images and Global News. Bristol: Intellect Books.

Andén-Papadopoulos, K. \& Pantti, M. (2013a) 'Re-imagining crisis reporting: Professional ideology of journalists and citizen eyewitness images', Journalism 14(7): 960-977.

Andén-Papadopoulos, K. \& Pantti, M. (2013b) 'The Media Work of Syrian Diaspora Activists: Brokering Between the Protest and Mainstream Media', International Journal of Communication 7: 1932-8036.

Beckett, C. \& Eltringham, M. (2011) “The line of verification': a new approach to objectivity for social media. College of Journalism'. Available from: http:// www.bbc.co.uk/blogs/collegeofjournalism/entries/c5d1a256-f8af-3c65-b59ce61fe223f200 (Accessed 27 February 2017).

Bennett, W. L. \& Segerberg, A. (2011) 'Digital media and the personalization of collective action: Social technology and the organization of protests against the global economic crisis', Information, Communication \& Society 14(6): 770-799.

Bock, M. A. (2012) 'Citizen video journalists and authority in narrative: Reviving the role of the witness', Journalism 13(5): 639-653.

Browne, M. et al. (2015) 'Streets to screens: conflict, social media and the news', Information, Communication \& Society 18(11): 1339-1347.

Carruthers, S. L. (2011) The Media at War. Basingstoke: Palgrave Macmillan.

Chadwick, A. (2017) The Hybrid Media System: Politics and Power. Oxford: Oxford University Press.

Curran, J. et al. (2016) Misunderstanding the Internet. Oxon: Routledge.

Gamson, W. \& Wolfsfeld, G. (1993) 'Movements and media as interacting systems', Annals of the American Academy of Political and Social Science 528: 114-125. 
Gil de Zúñiga, H. et al. (2012) 'Social media use for news and individuals' social capital, civic engagement and political participation', Journal of Computer-Mediated Communication 17(3): 319-336.

Grayson, L. (2015) 'Citizen Photojournalism', Journalism Practice 9(4): 568-579.

Greenwood, K. \& Thomas, R. J. (2015) 'Locating The Journalism in Citizen Photojournalism', Digital Journalism 3(4): 615-633.

Hadland, A. et al. (2017) 'Mobile phones and the news: How UK mainstream news broadcasting is stalling the video revolution', Convergence: The International Journal of Research into New Media Technologies (online first).

Hanitzsch, T. (2007) 'Deconstructing Journalism Culture: Toward a Universal Theory', Communication Theory 17(4): 367-385.

Hänska Ahy, M. (2016) 'Networked communication and the Arab Spring: Linking broadcast and social media', New Media \& Society 18(1): 99-116.

Hänska Ahy, M. \& Shapour, R. (2013) 'Who's Reporting the Protests? Converging Practices of Citizen Journalists and two BBC World Service Newsrooms, from Iran's Election Protests to the Arab Uprisings' Journalism Studies 14(1): 29-45.

Harkin, J. et al. (2012) 'Deciphering User-generated content in transitional societies: A Syria Coverage Case Study', Report by the Centre for Global Communication Studies, Annenberg School for Communication, Available from: http:// www.global.asc.upenn.edu/app/uploads/2012/03/Internews_Syria_updated.pdf (Accessed 25 February 2017).

Harrison, J. (2010) 'User-generated content and gatekeeping at the BBC hub', Journalism Studies 11(2): 243-256.

Holton, A. E. et al. (2013) 'Whose News? Whose Values?', Journalism Practice 7(6): 720 737.

Johnston, L. (2017) 'New Content, New Challenges: UGC Use and Challenges Faced by BBC News Journalists Covering Events in Syria', in D. Caspi \& D. Rubinstein, eds. Reporting The Middle East: Challenges And Chances. Singapore: World Scientific Publishing Company. pp. 61-77.

Johnston, L. (2016) 'Social News = Journalism Evolution?', Digital Journalism 4(7): 899909.

Kperogi, F. A. (2011) 'Cooperation with the corporation? CNN and the hegemonic cooptation of citizen journalism through iReport.com.' New Media \& Society 13(2): 314-329.

Kristensen, N. N. \& Mortensen, M. (2013) 'Amateur Sources Breaking the News, Metasources Authorizing the News of Gaddafi's Death', Digital Journalism 1(3): 352-367. 
Lorenzo-Dus, N. \& Bryan, A. (2011) 'Recontextualizing participatory journalists' mobile media in British television news: A case study of the live coverage and commemorations of the 2005 London bombings', Discourse \& Communication 5(1): 23-40.

Madden, M. et al. (2017) How youth navigate the news landscape, Report by the Knight Foundation, Available from: https://kf-site-production.s3.amazonaws.com/ publications/pdfs/000/000/230/original/Youth_News.pdf (Accessed 3 March 2017).

Maheshwari, S. (2016) 'How Fake News Goes Viral: A Case Study', The New York Times, 20 November, Available from: http://www.nytimes.com/2016/11/20/business/ media/how-fake-news-spreads.html (Accessed 21 November 2016).

Mast, J. \& Hanegreefs, S. (2015) 'When News Media Turn To Citizen-Generated Images of War', Digital Journalism 3(4): 594-614.

Matheson, D. \& Allan, S. (2009) Digital war reporting. Cambridge: Polity

Milan, S. (2013) Social Movements and Their Technologies: Wiring Social Change. Basingstoke: Palgrave Macmillan

Mortensen, M. (2015) 'Connective witnessing: Reconfiguring the relationship between the individual and the collective', Information, Communication \& Society 18(11): 1393-1406.

Murrell, C. (2017) 'The global television news agencies and their handling of user generated content video from Syria', Media, War \& Conflict (online first).

Mythen, G. (2010) 'Reframing risk? Citizen journalism and the transformation of news', Journal of Risk Research 13(1): 45-58.

Olmstead, K. et al. (2014) News video on the Web: a growing if uncertain part of the news. Report by the Pew Research Centre, Available from: http://www.journalism.org/ 2014/03/26/news-video-on-the-web/ (Accessed 21 November 2017).

Pantti, M. (2013) 'Getting Closer?', Journalism Studies 14(2): 201-218.

Pantti, M. \& Sirén, S. (2015) 'The Fragility of Photo-Truth' Digital Journalism 3(4): 495512.

Paulussen, S. et al. (2007) 'Doing it together. Citizen participation in the professional news making process', in The Good, The Bad and The Unexpected. The user and the future of innovation and communication technologies. Available from: http://hdl.handle.net/ 1854/LU-367517 (Accessed 30 August 2017).

Peters, J. D. (2001) 'Witnessing', Media, Culture \& Society 23(6): 707-723.

Poell, T. \& Borra, E. (2012) 'Twitter, YouTube, and Flickr as platforms of alternative journalism: The social media account of the 2010 Toronto G20 protests', Journalism 13(6): 695-713. 
Rosen, J. (2008) 'Afterword: The people formerly known as the audience', in N. Carpentier $\&$ B. de Cleen, eds. Participation and media production: Critical reflections on content creation. Newcastle: Cambridge Scholars Publishing. pp. 163-165.

Sadiki, L. (2012) 'The professionalisation of revolution in Syria', Al Jazeera, Available from: http://www.aljazeera.com/indepth/opinion/2012/01/201211313229137341.html (Accessed 29 November 2017).

Saperstein, P. (2016) 'Mike Pence Booed at 'Hamilton' Performance', Variety, Available from: http://variety.com/2016/legit/news/mike-pence-hamilton-booedboos-1201922601/ (Accessed 29 November 2017).

Schudson, M. \& Anderson, C. (2009) 'Objectivity, Professionalism, and Truth Seeking in Journalism', in K. Wahl-Jorgensen \& T. Hanitzsch, eds. The Handbook of Journalism Studies. New York: Routledge. pp. 88-101.

Seib, P. (2007) New Media and the New Middle East. Basingstoke: Palgrave Macmillan

Steel, H. (2015) 'Streets to screens: mediating conflict through digital networks', Information, Communication \& Society 18(11): 1269-1274.

Tufekci, Z. \& Wilson, C. (2012) 'Social media and the decision to participate in political protest: Observations from Tahrir square', Journal of Communication 62(2): 363379.

Van Dijck, J. (2009) 'Users like you? Theorizing agency in user-generated content' Media, culture \& society 31(1): 41-58.

Wahl-Jorgensen, K. et al. (2010) 'Audience views on user-generated content: Exploring the value of news from the bottom up', Northern Lights: Film \& Media Studies Yearbook 8(1): 177-194.

Wardle, C. et al. (2014) Amateur footage: A global study of user-generated content in TV and online news output, Report by the Tow Center for Digital Journalism, Columbia University, Available from: http://towcenter.org/wp-content/uploads/ 2014/04/80458_Tow-Center-Report-WEB.pdf / (Accessed 10 November 2017).

Williams, A. et al. (2010) "Have they got news for us?' Audience revolution or business as usual at the BBC?' Journalism Practice' 5(1): 85-99.

1 Most news organizations have URL's where the public are invited to submit 'your stories, seen through your eyes and your lens', as CNN puts it (http:// edition.cnn.com/help/ireport.html). See for example France24's 'Become an Observer' (http:// observers.france24.com/en/), and BBC's 'How to share your stories, pictures and videos with BBC News' (http:/ / www.bbc.com/news/10725415). 